\title{
Migration of Atlantic salmon post-smolts in a fjord with high infestation pressure of salmon lice
}

\author{
Elina Halttunen ${ }^{1, *, * *}$, Karl-Øystein Gjelland ${ }^{2, * *}$, Kevin A. Glover ${ }^{3,4}$, \\ Ingrid Askeland Johnsen ${ }^{3}$, Rosa-Maria Serra-Llinares ${ }^{1}$, Øystein Skaala ${ }^{3}$, \\ Rune Nilsen $^{1}$, Pål-Arne Bjørn ${ }^{1}$, Ørjan Karlsen ${ }^{3}$, Bengt Finstad ${ }^{5}$, Ove T. Skilbrei ${ }^{3, \mp}$ \\ ${ }^{1}$ Institute of Marine Research (IMR), 9294 Tromsø, Norway \\ ${ }^{2}$ Norwegian Institute for Nature Research (NINA), 9296 Tromsø, Norway \\ ${ }^{3}$ Institute of Marine Research (IMR), 5817 Bergen, Norway \\ ${ }^{4}$ Institute of Biology, University of Bergen (UiB), 5020 Bergen, Norway \\ ${ }^{5}$ Norwegian Institute for Nature Research (NINA), 7485 Trondheim, Norway
}

\begin{abstract}
Understanding Atlantic salmon Salmo salar post-smolt coastal migration behaviour is crucial for predicting their exposure to ecological challenges such as the parasite salmon louse Lepeophtheirus salmonis. We compared the migration of acoustically tagged, hatchery-reared Atlantic salmon post-smolts of wild and domesticated origins from the inner, middle and outer part of a $172 \mathrm{~km}$ long aquaculture-intensive fjord in western Norway. Additionally, we examined if the timing of the release or treatment with an anti-parasitic drug (prophylaxis) altered migratory behaviour. We found no significant differences in mean progression rates among the 3 release locations, among genetic groups or between treatments (range: $11.5-16.9 \mathrm{~km} \mathrm{~d}^{-1}$ ). However, individual variation in progression rates and migratory routes resulted in large differences in fjord residence times (range: 2-39 d). Ocean-current directions during and after release affected swimming speed, progression rate and route choice, and for most post-smolts, swimming speeds were much higher than their progression rates out of the fjord. The predicted lice loads based on lice intensity growth rates on smolts held in sentinel cages throughout the fjord indicated that individuals taking $>10 \mathrm{~d}$ to exit the fjord in periods with high infestation pressure are likely to get lethally high sea-lice infestations. We conclude that, as migratory routes of $S$. salar post-smolts are hard to predict and migration times can stretch up to over a month, it is important to develop aquaculture management that keeps salmon lice levels down along all potential migration routes and during the full potential migratory period.
\end{abstract}

KEY WORDS: Migratory behaviour - Salmo salar - Lepeophtheirus salmonis · Acoustic telemetry · Management $\cdot$ Fish farming $\cdot$ Parasite

\section{INTRODUCTION}

In the spring and early summer of each year, wild Atlantic salmon (Salmo salar L.) smolts exit their native rivers and migrate through coastal waters on their way to oceanic feeding grounds. This first phase of the marine migration is also the most vulnerable; post-smolts may experience high mortality due to the physiologically challenging transition from freshwater to saltwater habitat (Strand \& Finstad 2007,

\footnotetext{
*Corresponding author: elina.halttunen@gmail.com

${ }^{* *}$ Shared first authorship

${ }^{\mp}$ Deceased, author of the first draft of the manuscript
}

Strand et al. 2011, Thorstad et al. 2012a), and due to predation (Hvidsten \& Lund 1988, Handeland et al. 1996). However, in some regions, this journey is also being made increasingly difficult through the expansion of coastal aquaculture, as farmed fish in open net pens can function as source populations for diseases and parasites (Tully \& Nolan 2002, Skilbrei et al. 2013, Vollset et al. 2016a). The salmon louse Lepeophtheirus salmonis is one such parasite that occurs in coastal waters in higher than natural concentra-

(C) The authors 2018. Open Access under Creative Commons by Attribution Licence. Use, distribution and reproduction are unrestricted. Authors and original publication must be credited. 
tions in Atlantic salmon aquaculture-dense regions, which has led to higher infestation rates in wild fish in these regions (Bjørn et al. 2011, Serra-Llinares et al. 2014, 2016, Shephard et al. 2016).

When free-swimming salmon lice copepodids encounter salmonid fish, they attach to the fish and feed on their skin, blood and mucus. This parasitic feeding can negatively affect the host's feeding behaviour and swimming capability (Overli et al. 2014), increase predation risk (Godwin et al. 2015, Peacock et al. 2015), and result in osmoregulatory failure and death (Birkeland 1996, Bjørn \& Finstad 1998, Finstad et al. 2000). Protecting Atlantic salmon post-smolts against salmon lice using a prophylactic treatment prior to release can increase their marine survival (measured as return rates), in comparison to a control group (Gargan et al. 2012, Jackson et al. 2013, Skilbrei et al. 2013, Vollset et al. 2016b). However, the scope of this effect seems to be highly variable, with the highest differences between groups occurring in years when overall marine survival is low (Vollset et al. 2016b). As the prophylactic treatment is effective for only a few weeks after release, these studies imply that salmon lice infestation during early fjord and coastal migration can form a significant component of overall marine mortality of the post-smolts.

Salmon lice infestation found on wild salmonids caught during their coastal migration is one of the key components in regulating salmon farming in Norway (Taranger et al. 2015). Many of the management regimes aim to reduce encounter rates of salmon lice and wild fish (e.g. synchronized fallowing, spring delousing). In order to design and evaluate different management regimes, modelling encounter rates can be used to test diverse scenarios. However, this requires detailed knowledge of postsmolt swimming speeds and migration routes, parasite distribution, as well as hydrography and currents. When aiming to understand the potential encounter rate of salmon lice and wild fish, it is important to note that post-smolts do not necessarily swim to the sea via the most direct route. Most migration studies report post-smolt progression rates as speed from the release point along the shortest route until a subsequent detection point further out in the fjord, thereby potentially biasing downwards the movement of the fish and their encounter rates with salmon lice.

In this work, we tracked and compared progression rates and routes of individual acoustically tagged Atlantic salmon post-smolts in a $172 \mathrm{~km}$ long aquaculture-intensive fjord, and addressed the potential influence of release location, genetic origin, release timing, prophylaxis effect, hydrography, and the discrepancy between swimming speed and progression rate. The combination of progression rate experiments with contemporary salmon lice infection rate experiments in the same fjord adds to the novelty of the study. The primary aim of the study was to assess the consistency of post-smolt migration behaviour through the fjord system, and the consequences thereof on predicted residency times and salmon lice loads upon exit.

\section{MATERIALS AND METHODS}

\section{Overall study design}

In order to study the progression rate and routes of Salmo salar post-smolts, hatchery-reared smolts of both domesticated and wild genetic backgrounds were raised from fertilized eggs at the Institute of Marine Research station in Matre, western Norway, in identical rearing conditions. The reason for using fish of different genetic backgrounds was to be able to compare progression rates between different strains of fish, and to ensure large enough sample sizes. All fish were tagged with acoustic transmitters, and thereafter released from the estuaries of 3 different rivers in the Hardangerfjord: Opo in the innermost part, Guddal in the middle part and Etne in the outer part of the fjord (conducted in 2006, 2007 and 2014, respectively).

\section{Study area}

The Hardangerfjord is one of the largest fjords in Norway, with a total length of $172 \mathrm{~km}$ from the innermost River Opo to the fjord mouth Bømlafjorden (Fig. 1). On the northwest side of the fjord, there are 3 straits: Lukksundet, Langenuen and Stokksundet (Fig. 1). The fjord currently holds one of the highest densities of Atlantic salmon farms in Norway, with a total standing stock of $\sim 94000 \mathrm{t}$ (on 31 December 2016; Directorate of Fisheries). Approximately 27 rivers containing wild anadromous salmonid populations drain into Hardangerfjord (Skaala et al. 2014).

Water discharge in River Opo varies typically between a low $3 \mathrm{~m}^{3} \mathrm{~s}^{-1}$ during winter and $80 \mathrm{~m}^{3} \mathrm{~s}^{-1}$ during summer (sildre.nve.no), and the annual river catch of Atlantic salmon varied between 30 and 273 individuals in the years the river has been open for angling (Ø. Skaala pers.comm.). Water discharge in River Guddal varies typically from a low $1 \mathrm{~m}^{3} \mathrm{~s}^{-1}$ dur- 


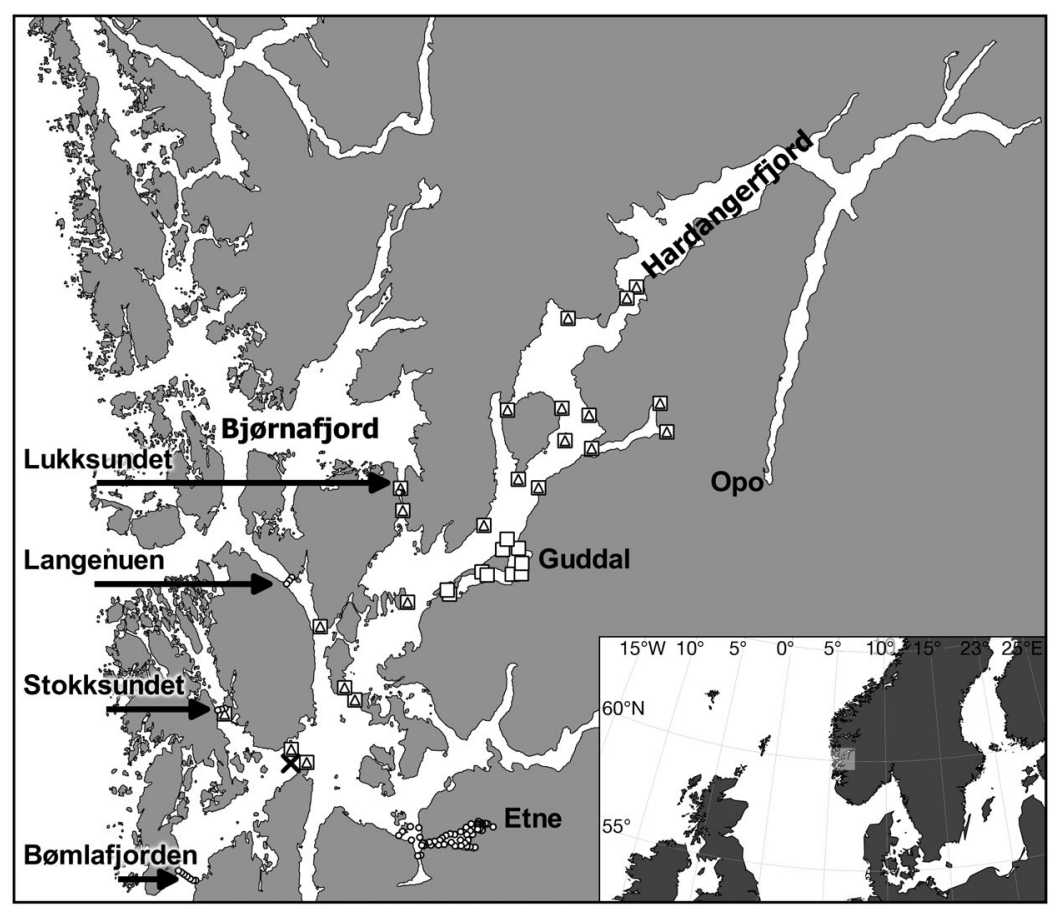

Fig. 1. Study area of Hardangerfjord and the neighbouring Bjørnafjord; rivers Opo, Guddal and Etne; fjord mouth Bømlafjorden; and straits Stokksundet, Langenuen and Lukksundet. Hydrophone positions for $2006(\Delta), 2007(\square)$ and 2014 (O) are shown. The X marks the location of the modelling of the alongfjord current. Inset: location of the Hardangerfjord system (light grey square) in northern Europe

ing winter to $8 \mathrm{~m}^{3} \mathrm{~s}^{-1}$ during summer (sildre.nve.no), and the river holds a small number of wild Atlantic salmon spawners (Skaala et al. 2012). In River Etne, water discharge typically varies from $2 \mathrm{~m}^{3} \mathrm{~s}^{-1}$ in winter to $30 \mathrm{~m}^{3} \mathrm{~s}^{-1}$ during spring and summer (sildre. nve.no), and the spawning run typically includes 1000-2000 returning Atlantic salmon adults each year (A. Harvey unpubl. data).

\section{Fish}

All fish used in these experiments were $1 \mathrm{yr}$ old hatchery-reared $S$. salar post-smolts produced and tagged at the Matre Research Station. Fish used in the first release experiment in 2006 originated from the wild River Lærdal strain, the domesticated Mowi strain, and F1 hybrids between them. Marine Harvest provided the eggs and sperm of the Mowi strain, which had been exposed to domestication for approximately 10 generations when this study was conducted (details in Glover et al. 2009). In addition, eggs and sperm were collected from first- and second-generation spawners of the River Lærdal strain, kept in the Norwegian Gene Bank for Atlantic salmon (located in Eidfjord). Fish used in the second release experiment conducted in 2007 also originated from the wild Lærdal strain, and domesticated Atlantic salmon originating from the commercial Aquagen strain. This strain is similar in age to the Mowi strain and at the time of the experiment had been exposed to domestication and selection for a range of economically important traits. In the third and final release experiment conducted in 2014, smolts were produced from eggs and sperm collected from wild adults caught directly from River Etne.

\section{Tagging}

After recording length and weight, each fish was implanted with an individual ultrasonic transmitter (Vemco; in 2006 and 2007: V9-6L, diameter $9 \mathrm{~mm}$, length $20 \mathrm{~mm}$, weight in air $3.3 \mathrm{~g}, 20-60$ s delays with $60 \mathrm{~d}$ life; in 2014: V8-4H, diameter $8 \mathrm{~mm}$, length $20.5 \mathrm{~mm}$, weight in air $2 \mathrm{~g}, 40-80 \mathrm{~s}$ delays with $60 \mathrm{~d}$ life) into the body cavity following the general procedures described in Finstad et al. (2005) and Hedger et al. (2011) (for more details, see Table S1 in the Supplement at www.int-res.com/ articles/suppl/m592p243_supp.pdf). The release dates in May-June in all 3 years were within the outmigration period of the local wild salmonid populations at the release locations.

\section{Release experiments}

\section{Estuary of Opo in 2006}

Smolts of the River Lærdal strain, the domesticated Mowi strain, and their F1 hybrids (in total 40 individuals) were tagged on 2 and 5 June, transported to tanks supplied with running freshwater by the estuary of the River Opo and released into the estuary on the evening of 5 June (see Tables 1 \& S1). Twenty-two hydrophone (VR2, Vemco) receivers were deployed, attached to submerged floats at $\sim 10 \mathrm{~m}$ depth and moored to the bottom, in the middle and outer part of the fjord, including 2 receivers in Lukksundet (Fig. 1). 


\section{Estuary of Guddal in 2007}

Experimental fish, originating from the River Lærdal and the domesticated Aquagen strain (see Tables $1 \& \mathrm{~S} 1$ ), were tagged on 1 June and transported to tanks supplied with running freshwater by the River Guddal on 12 June. Fish of both strains were released in equal numbers in the estuary of the river 4 times on 15 June (Table S1). In addition to the hydrophones deployed in the 2006 releases, 10 hydrophone (VR2W, Vemco) receivers were deployed in positions close to the release site to investigate the migration direction of the 4 different releases in 2007 (Fig. 1, Table S1).

\section{Estuary of Etne in 2014}

Smolts of the River Etne strain were tagged (28-29 April) and treated (14 and 28 May), transported to Etnefjord and released in 2 batches (18 May and 9 June, hereinafter termed early and late release; see Tables 1 $\&$ S1). Half of the fish (equal numbers from both release groups, $2 \times 30$ fish) were treated with a $30 \mathrm{~min}$ bath of substance EX (Pharmaq), which protects the fish against lice infestation for up to $12 \mathrm{wk}$, according to the manufacturer (E. Aksnes, Pharmaq, pers. comm.; see Skilbrei et al. 2015 for an efficacy test of substance EX). Substance EX is currently in the process of being certified for use in commercial aquaculture and the composition will be released later. Prior to release, the fish were piped directly from the transport tank to a $5 \times 5 \times 5 \mathrm{~m}$ net pen moored in the inner part of the Etnefjord, and kept for approximately $48 \mathrm{~h}$.

Fifty-three receivers (VR2W) were deployed to cover the area up to a distance of $11.4 \mathrm{~km}$ from the release site, including 3 receivers located in the river. Fifteen extra receivers were deployed at the 4 exits from Hardangerfjord (Fig. 1). Distance between the receivers varied between 250 and $530 \mathrm{~m}$. Close to the release site, receivers were deployed attached to submerged floats moored to the bottom and kept at depths ranging between 5 and $52 \mathrm{~m}$. In deep areas (>200 $\mathrm{m}, 7$ receivers), the receivers were deployed at depths between 40 and $50 \mathrm{~m}$, and the mooring incorporated underwater acoustic release devices (SubSeaSonics). Three sentinel tags were used to document hydrophone array detection performance (see Fig. S1 in the Supplement for detection rates over time). Detection probability is normally high $(>0.75)$ up to some range, whereafter it decreases rapidly (Gjelland \& Hedger 2013, 2017, Huveneers et al. 2017). Sentinel tag data indicated that the detection probability was high or fairly high at least for ranges up to $300 \mathrm{~m}$.

\section{Tracking}

The receiver design in 2006 and 2007 was not designed to give $100 \%$ detection of all individual fish as they migrated out of the fjord, but to provide information on progression rates and routes of the different genetic strains of Atlantic salmon post-smolts. In contrast, the receiver array deployed in 2014 was designed with high coverage within Etnefjord, and with receiver lines giving full coverage of all optional exit routes from the main part of Hardangerfjord (Fig. 1). Telemetry data from 2014 was inspected for each tag by plotting detection location by time. The data had no indications of false detections and therefore was used without further filtering (see Fig. S2 in the Supplement for individual tracks).

\section{Final groups and analysis}

Two individuals from the Guddal release (2007) and 3 from the Etne release (2014) were removed from the analysis due to a lack of sufficient transmissions. The effective group sizes used in further analyses were therefore 40, 70 and 117 for the Opo, Guddal and Etne releases, respectively (see Table 1). These effective group sizes were used when calculating percentage observed (all years) and minimum survival (2014). Survival is reported as minimum survival, as some post-smolts could have passed the outer receiver lines unobserved, and assuming that the tags observed passing these lines were reporting for a live post-smolt and not a predator (e.g. Gadus morhua or S. trutta common in the study area) that had consumed the fish. Even though few studies on predation rates exist from the study area (but see Gjelland et al. 2014), predation is known to be a considerable but variable source of mortality for salmonids entering the sea (Thorstad et al. 2012a,b, Vollset et al. 2016c). However, the behaviour of the predators usually differs from the uni-directional migration behaviour of Atlantic salmon (Gjelland et al. 2014). The number of observed individuals between groups was compared with the log likelihood ratio (G-test) of independence (G.test function in the package RVAideMemoire, https://CRAN.Rproject.org/package=RVAideMemoire) .

Progression rates $\left(\mathrm{km} \mathrm{d}^{-1}\right)$ for the tagged postsmolts from all 3 releases were calculated using the 
shortest in-sea distance from the release site to the last detection site (2006 and 2007), or the receiver lines covering the 4 possible migration routes (2014), measured through the middle of the fjord, divided by the time between the release and last detection time.

As the receiver coverage was high for the 2014 release (Fig. 1), we could obtain estimates of mean individual position for every $30 \mathrm{~min}$ within the Etnefjord using the centre of activity (CA) method (mean receiver position algorithm, Simpfendorfer et al. 2002). These CA position estimates were subsequently used to obtain direct estimates of the actual swimming speed of the post-smolts within the area.

We compared the CA swimming speeds to the progression rate estimates in 2014 in order to get an indication of the degree to which individuals chose the shortest route from the release location and out to the ocean. Note that throughout this paper, both progression rate estimates and CA swimming speed estimates refer to the speed over ground, not to the speed through the surrounding water. For readability, from here on, CA swimming speeds are simply referred to as swimming speeds.

As progression rates were measured along fixed distances rather than fixed time, we used harmonic mean estimates of the progression rate weighted by the travelled distance for each fish when calculating the average time needed to migrate from the river outlet to the ocean. Statistical effects of (1) genetic group (domesticated, wild, and hybrids, all years) and (2) prophylaxis treatment and release group in 2014 on progression rates were tested with ANOVA. The effect of body size on progression rate was tested with ANCOVA, using release (2006, 2007, 2014 early and 2014 late) as a factor and fish length centred and scaled by 2 standard deviations as a covariate. For all statistical tests of progression rates, we used the reciprocal of the progression rate as the response variable and weighting by emigration route length to conform to harmonic mean estimation.

Swimming speed can be expected to relate to body length (BL) by a power function (Ware 1978); to investigate the power coefficient, both the swimming speeds and progression rates were modelled as a function of BL (log-log model) using a linear mixed effects model with release group as a random effect.

\section{Hydrography}

To investigate the currents' potential influence on the released post-smolts' migration routes, we selected the along-fjord current (see position in Fig. 1) from the hydrodynamic model NorKyst800 (Albretsen et al. 2011). The currents are shown with hourly resolution, and to illustrate the general movement of the water, values were also filtered using a 4 th-order Butterworth filter with a cut-off frequency of $(24 \mathrm{~h})^{-1}$. The model-predicted temperature at $2 \mathrm{~m}$ depth was used to investigate temperature conditions in the fjord at the time of the releases.

\section{Infestation pressure of salmon lice}

The infestation pressure of salmon lice Lepeophtheirus salmonis in the study area was monitored using 2 methods: trawling for wild post-smolts, and placing sentinel cages in strategic positions in the fjord.

Trawling was conducted each year during JuneJuly (ISO standard weeks 20-23 in 2006, 21-22 in 2007 and 19-21 in 2014). A specially designed FISHLIFT trawl (Holst \& McDonald 2000) was used for sampling in order to avoid loss of both scales and lice on the caught fish. In order to sample wild Atlantic salmon post-smolts with a representative infestation level throughout the entire fjord migration route, trawling was concentrated in the outer parts of the Hardangerfjord, and as close to the shoreline as possible.

Sentinel cages were stocked with hatchery-reared Atlantic salmon smolts for an average of $16 \mathrm{~d}$ in 1 to 4 periods in different parts of the main body of the Hardangerfjord in 2006, 2007 and 2014, at 35$1111 \mathrm{~m}$ from the shoreline (Fig. S3 in the Supplement). The rate of salmon lice intensity increase on the sentinel smolts was calculated as the rate of infection change over time: $\left(I_{\text {end }}-I_{\text {start }}\right) \times T^{-1}$, where $I_{\text {start }}$ and $I_{\text {end }}$ denote salmon lice infestation intensity (count of lice on each smolt individual) at the start and end of the sentinel period, and $T$ is the duration of the period (in days).

\section{Predicted residency times and salmon lice infestation loads}

Extrapolating from the ANCOVA model, we calculated the time needed to migrate from the river mouths to the ocean along the main part of Hardangefjord for a standardized smolt of $142 \mathrm{~mm}$ length (mean smolt length in trawl catches). Using the mean and the 75th and 95th percentiles as well as maximum lice intensity growth rates within each cage, averaged over all cages, we predicted the respective 
lice infection intensity after 10, 20, 30 and $40 \mathrm{~d}$ for a post-smolt swimming in Hardangerfjord. The mean was calculated as a geometric mean with a linear mixed effects model, assuming a Poisson distribution and using cage ID as a random effect.

\section{RESULTS}

\section{Observed individuals}

Fourteen of the 40 post-smolts (35\%) released in the estuary of River Opo in 2006 were detected in the middle and outer parts of the fjord, 72-150 km from the release site. Twenty-nine of the 78 post-smolts (37\%) released by the River Guddal in 2007 were detected at the outer part of the fjord 29-47 km from the release site. Eighty-nine of the 117 released postsmolts (76\%) in Etnefjord in 2014 were detected at the receiver lines in the 3 adjoining straits or the fjord mouth 40-59 $\mathrm{km}$ from the release site. Due to the coverage of all potential exits in 2014, this can be considered as the minimum survival of these fish out of the main part of Hardangerfjord. There was no difference in the number of observations between genetic groups (8/19 vs. 5/19 in 2006 and 12/39 vs. $17 / 39$ in 2007; $G_{2006}=0.52, \mathrm{df}=1, \mathrm{p}=0.47$ and $G_{2007}=$ 0.63 , df $=1, \mathrm{p}=0.42$ ), treatments (treated, 43/59 vs. control, 46/58; $G=0.09$, df $=1, \mathrm{p}=0.76$ ) or releases (early, 49/57 vs. late, $40 / 60 ; G=0.81$, df $=1, \mathrm{p}=0.37$ ) in 2014 (Table 1).

\section{Migratory routes}

Most (13/14) of the detected Opo fish were registered within the main part of the fjord, and only 1 was detected at the Lukksundet exit. In contrast, more than half $(16 / 29)$ of the detected Guddal fish were registered at the Lukksundet exit and 1 individual was detected at the entrance of the Langenuen exit, while the others were distributed towards the fjord mouth. The initial direction of migration away from the release site in Guddal changed during the release day. Following the 2 first releases, the majority moved north, but following the 2 last releases, the majority moved west. Consequently, a significantly higher number of the post-smolts moving northbound entered the Lukksundet exit as opposed to the postsmolts moving west after release (10/32 vs. 3/27; $G=$ $4.42, \mathrm{df}=1, \mathrm{p}=0.04)$. Migration routes did not differ between treated and control Etne-release fish, but earlyrelease fish only used the 2 closest exits Stokksundet and Bømlafjorden, whereas late-release fish used all 4 exits. The smolts utilized the whole breadth of the fjord when exiting through Bømlafjorden, though a substantial proportion of them migrated close to the northern shore (Fig. S4 in the Supplement).

\section{Progression rates and swimming speeds}

Progression rates varied greatly among individuals in all 3 release years $\left(2.4-45.8 \mathrm{~km} \mathrm{~d}^{-1}\right.$; Table 1,

Table 1. Number of salmon Salmo salar tagged in the experiments, release date, how many were later acoustically detected, average length and mass $( \pm 1 \mathrm{SD})$, average distance travelled from release to last detection point $( \pm 1 \mathrm{SD})$, and average progression rates in 3 different units $( \pm 1 \mathrm{SD})$. Treated/untreated refers to whether fish were protected from salmon lice Lepeophtheirus salmonis by bathing with substance EX prior to release. Sizes of final groups in parentheses in the 'Tagged' column (after removing malfunctioning tags and dead individuals). For more details, see Table S1 in the Supplement. BL: body length

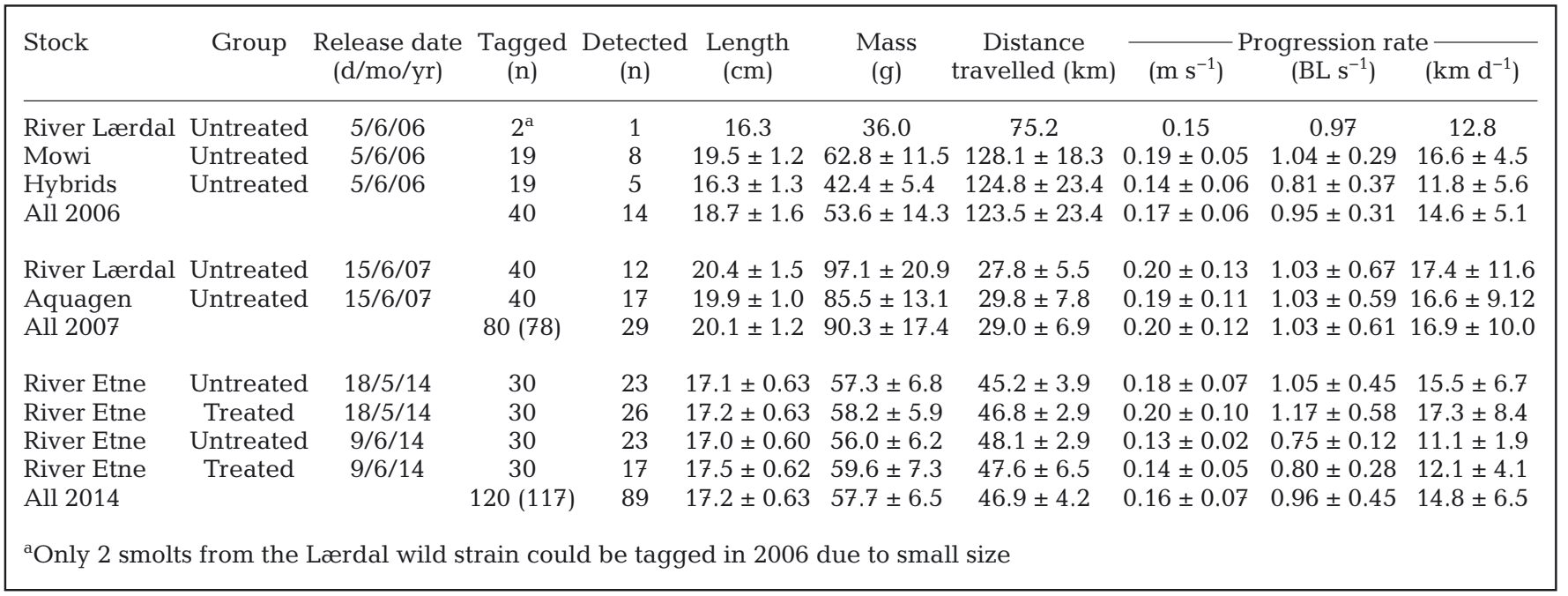



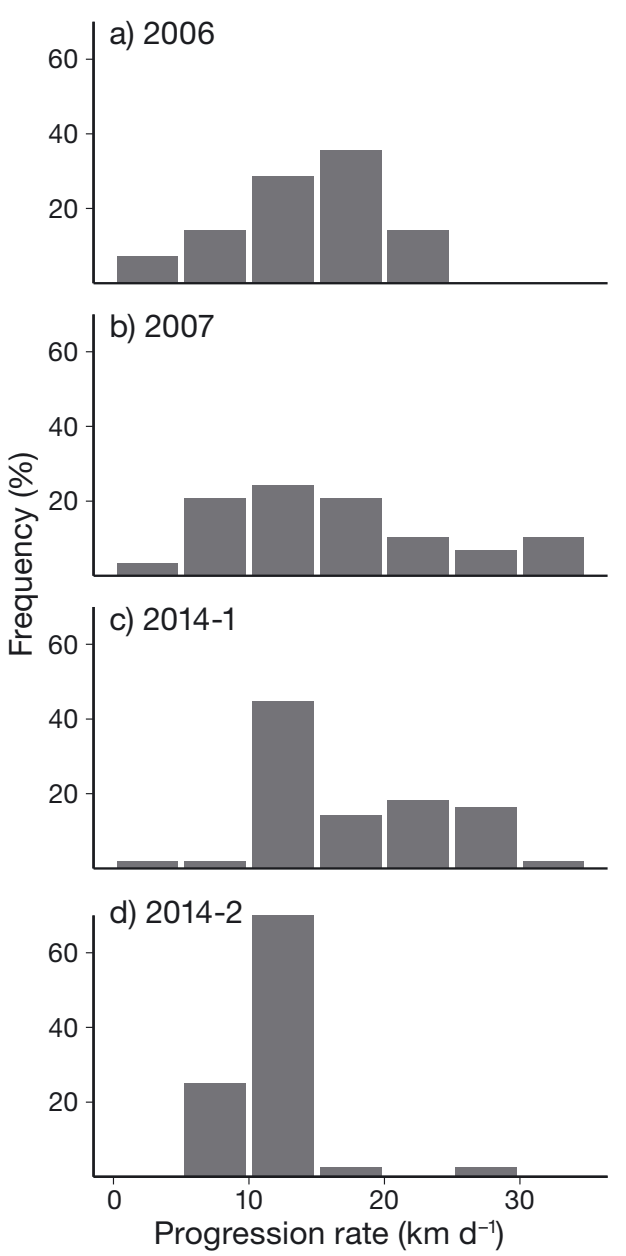

Fig. 2. Progression rates of released groups of Salmo salar in (a) 2006, (b) 2007, (c) 2014-1 (Etne, early release) and (d) 2014-2 (Etne, late release)

Fig. 2). Despite large individual variation, the arithmetic mean progression rates from release to the last observed location were very similar between all 3 years (14.6, 16.9 and $14.8 \mathrm{~km} \mathrm{~d}^{-1}$ in 2006, 2007 and 2014 , respectively). The overall harmonic mean progression rate for all tagged fish was $12.4 \mathrm{~km} \mathrm{~d}^{-1}$, and the yearly harmonic mean progression rates for 2006, 2007, 2014 early and 2014 late releases were 12.4, 11.5, 14.7 and $10.9 \mathrm{~km} \mathrm{~d}^{-1}$, respectively. There was no difference in progression rate or swimming speed between the genetic groups (ANOVA: $F_{4,127}=1.04$, $\mathrm{p}=0.4$ ). Progression rates were significantly different between release groups in 2014, but we found no treatment effect (ANOVA; Fig. 3a, Table 2). Early Etne-release fish (that were later observed at one of the outer receiver lines) had slower individual swimming speeds than late-release fish (mean 1.7 and $2.5 \mathrm{BL} \mathrm{s}^{-1}$, respectively, ANOVA: $F_{1,87}=54.7, \mathrm{p}<$ 0.001 ; Fig. $3 \mathrm{~b}, \mathrm{c})$. In other words, while the progres-
Table 2. ANOVA for effects of release and treatment on the reciprocal of the progression rate in the 2014 experiment

\begin{tabular}{|lccccc|}
\hline & df & SS & MS & $F$ & $p$ \\
\hline Release & 1 & 0.57 & 0.56 & 13.5 & 0.0004 \\
Treatment & 1 & 0.04 & 0.04 & 1.0 & 0.3 \\
Release $\times$ Treatment & 1 & 0.002 & 0.002 & 0.1 & 0.8 \\
Residuals & 85 & 3.55 & 0.04 & & \\
\hline
\end{tabular}

sion rates and swimming speeds were similar for most of the early-release fish, the late-release fish had substantially lower progression rates than swimming speeds (Fig. 3c). Progression rate was positively correlated to body size, although the relationship was statistically weak (ANCOVA: $F_{1,127}=2.37, \mathrm{p}=$ 0.13 ) (Fig. 3d). BL power coefficients of 0.25 and 0.57 were found for progression rate and swimming speed, respectively, but these were not significantly different from zero ( $\mathrm{p}=0.72$ and 0.42 , respectively). Many fish swam back and forth before they exited the Etnefjord and the inner receiver coverage area (see Fig. S2 for fish track plots).

\section{Hydrography at release times}

Both the 2006 and 2007 releases were followed by long outflows (Fig. 4). During the release day in Guddal in 2007, the first release was during the flood tide, the 2 next releases during the ebb tide, and the last again during the flood tide. In Etne in 2014, the water transport was stronger and more characterized by episodes directed into and out of the fjord. The early release in 2014 was during the ebbing of an inflow, where the current was directed both into and out of the fjord in the following days, having a net transport out of the fjord. The late release on the other hand was during a strong inflow episode. Model-predicted temperature at $2 \mathrm{~m}$ depth was approximately $10^{\circ} \mathrm{C}$ at the release time in $2006,12^{\circ} \mathrm{C}$ in 2007 , and $10^{\circ} \mathrm{C}$ and $15^{\circ} \mathrm{C}$ during the 2 releases in 2014 (Figs. S5-S8 in the Supplement).

\section{Observed infestation pressure of salmon lice in the fjord}

In total, 152 wild post-smolts $(113,10$ and 29 for 2006, 2007 and 2014, respectively; mean length and weight of $14.2 \mathrm{~cm}$ and $24.8 \mathrm{~g}$ ) were caught by trawl in the outer part of the Hardangerfjord in the 3 study years. The prevalence (\% of sampled hosts infected) and mean intensity (lice per infected host) of salmon 

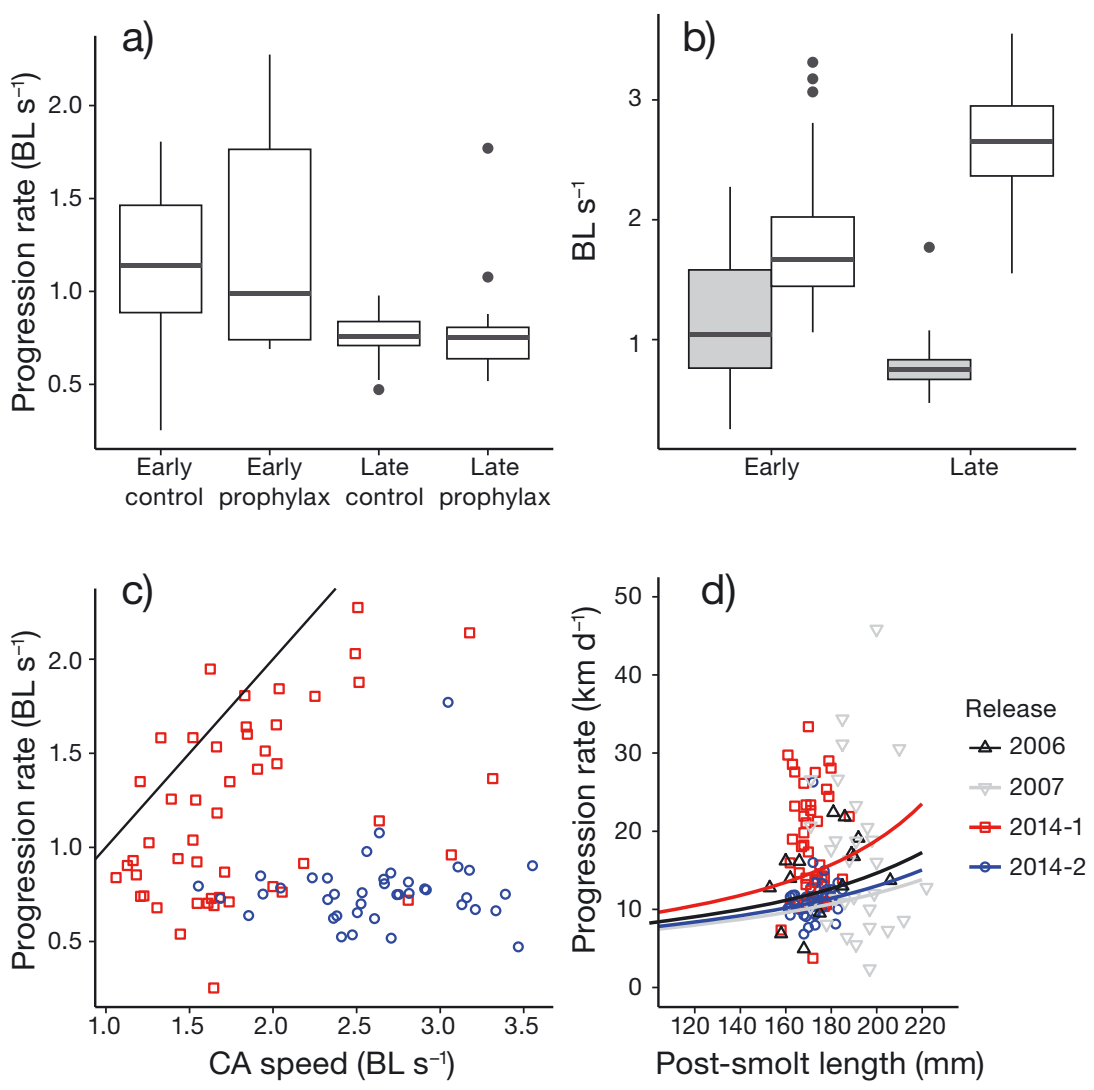

Fig. 3. (a) Progression rates for control and prophylaxis (using substance EX) groups of Salmo salar, for early and late 2014 releases. (b) Progression rates (grey fill) and swimming speeds (white fill) (determined by 30 min estimates of centre of activity) for early and late 2014 releases. Bar: median; box: 25 th -75 th percentiles, whiskers: extend to the largest and smallest value less than $1.5 \times$ the interquartile range from the box; dots: outliers, observations outside these defined ranges. (c) Relationship between individual progression rates and centre of activity (CA) swimming speeds for early (red) and late (blue) 2014 releases. Black line indicates line of unity (1:1 relationship). (d) Progression rate was positively, but not significantly, related to body length (BL) (curves indicate BL influence from the ANCOVA model, extrapolated down to $110 \mathrm{~mm}$ fish, which is at the lower size end for wild smolts). 2014-1 is early release, 2014-2 is late release lice infestation for all trawls within each year ranged from $21-48 \%$ and 2.3-6.5 lice host ${ }^{-1}$, respectively.

A total of 2783 hatchery-reared post-smolts (mean length and weight of $20.2 \mathrm{~cm}$ and $80 \mathrm{~g}$ ) were held in the sentinel cages in different parts of the main body of the Hardangerfjord in the 3 study years. The mean prevalence and intensity of salmon lice infestation ranged from $20-94 \%$ and $1.26-4.01$ lice host ${ }^{-1}$, respectively, for cage deployments within each year (Table S2 in the Supplement). Intensity growth rates of lice on post-smolts in sentinel cages varied from 0-3.11 lice $\mathrm{d}^{-1}$ (Fig. 5, Table S2).

\section{Residency times and consequences for salmon lice infestation}

Rapidly migrating Opo post-smolts $\left(25 \mathrm{~km} \mathrm{~d}^{-1}\right)$ would have used approximately $1 \mathrm{wk}$ to migrate from river mouths to the open ocean along the main part of Hardangerfjord (Table 3). However, $142 \mathrm{~mm}$ Opo smolts with mean progression rates $\left(10.1 \mathrm{~km} \mathrm{~d}^{-1}\right)$ would have nearly used $3 \mathrm{wk}$, and it would have taken slow migrators $\left(5 \mathrm{~km} \mathrm{~d}^{-1}\right)>5$ wk to reach open sea regardless of the chosen route (Table 3). The Etne post-smolts had comparable progression rates

Table 3. Shortest and longest alternative migration routes out of Hardangerfjord from each of the 3 rivers through fjord mouth and straits, and calculations of migration duration using progression rates (PR) for a standardized Salmo salar smolt of $14.2 \mathrm{~cm}$ length ( $\mathrm{PR}_{\text {mean }}$ predictions from ANCOVA model) as well as PR of 5, 15 and $25 \mathrm{~km} \mathrm{~d}^{-1}$. Etne $1=$ early release, Etne $2=$ late release

\begin{tabular}{|c|c|c|c|c|c|c|c|c|c|c|c|}
\hline \multirow[t]{3}{*}{ River } & \multirow{3}{*}{$\begin{array}{c}\text { Mean PR } \\
\left(\mathrm{km} \mathrm{d}^{-1}\right)\end{array}$} & \multicolumn{5}{|c|}{ Shortest migration route } & \multicolumn{5}{|c|}{ Longest migration route } \\
\hline & & \multirow{2}{*}{$\begin{array}{l}\text { Distance } \\
(\mathrm{km})\end{array}$} & \multirow{2}{*}{$\mathrm{PR}_{\text {mean }}$} & \multicolumn{3}{|c|}{ Duration $(\mathrm{d})$} & \multirow{2}{*}{$\begin{array}{c}\text { Distance } \\
(\mathrm{km})\end{array}$} & \multirow{2}{*}{$\mathrm{PR}_{\text {mean }}$} & \multicolumn{2}{|c|}{ Duration $(\mathrm{d})$} & \multirow[b]{2}{*}{$\mathrm{PR}_{25}$} \\
\hline & & & & $\mathrm{PR}_{5}$ & $\mathrm{PR}_{15}$ & $\mathrm{PR}_{25}$ & & & $\mathrm{PR}_{5}$ & $\mathrm{PR}_{15}$ & \\
\hline Opo & 10.1 & 183 & 14.8 & 36.6 & 12.2 & 7.3 & 196 & 19.4 & 39.2 & 13.1 & 7.8 \\
\hline Guddal & 8.8 & 64 & 5.5 & 12.8 & 4.3 & 2.6 & 82 & 9.3 & 16.4 & 5.5 & 3.3 \\
\hline Etne 1 & 11.9 & 60 & 4.1 & 12.0 & 4.0 & 2.4 & 109 & 9.1 & 21.8 & 7.3 & 4.4 \\
\hline Etne 2 & 9.3 & & 5.5 & & & & & 11.7 & & & \\
\hline
\end{tabular}




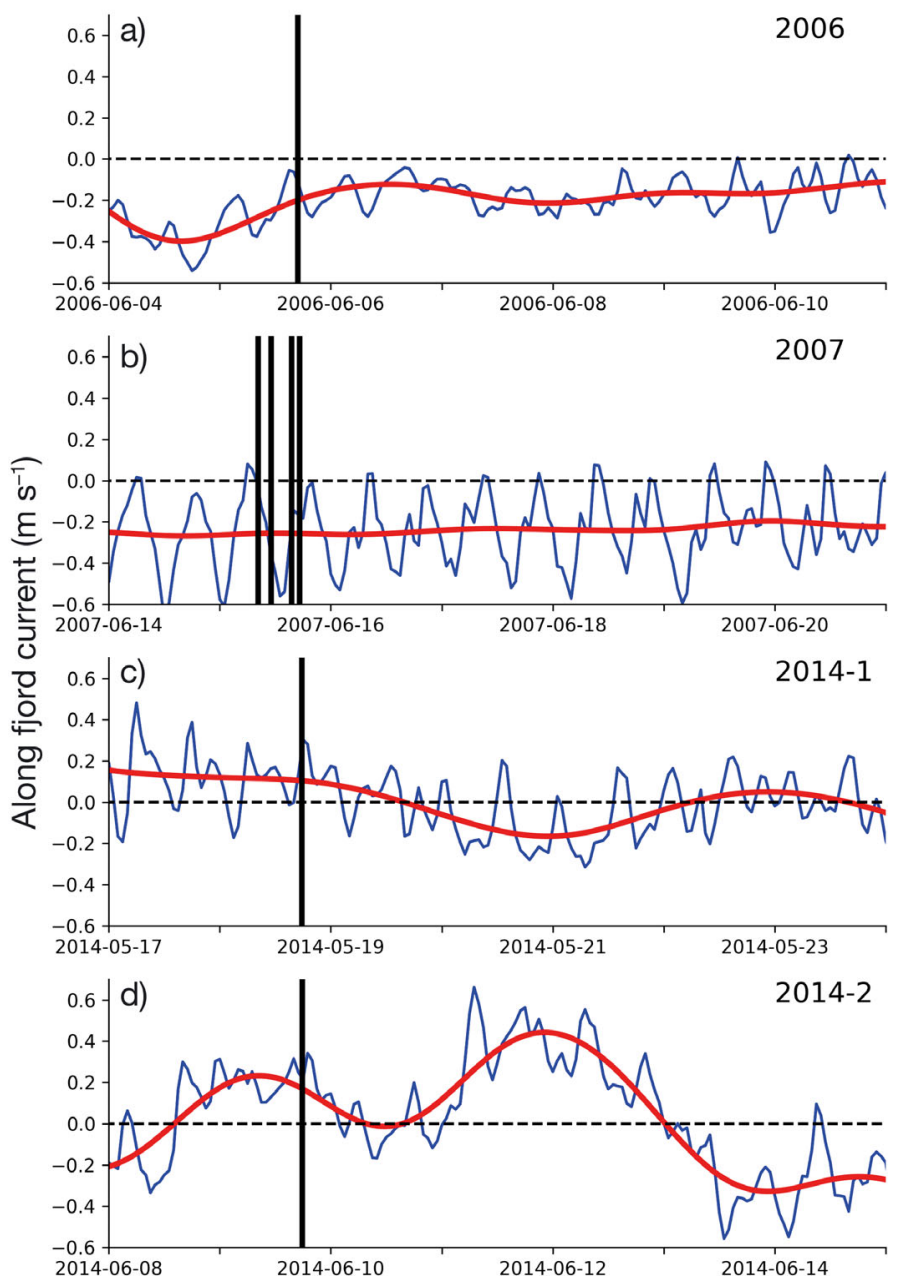

Fig. 4. Along-fjord component of the current from $2 \mathrm{~d}$ prior to $5 \mathrm{~d}$ after each release (vertical black lines) of Salmo salar in (a) 2006 in Opo, (b) 2007 in Guddal and (c,d) 2014 in Etne (1: early release; 2 : late release). Blue line: hourly values of the current, red line: Butterworth filtered currents. Current was filtered to make the in- and out-flow transport of water more apparent

to those released from Opo and Guddal, but the observed difference in travelled distance between alternative migration routes was largest for the Etne post-smolts, with the direct route out of the main fjord being under half the distance of the longest alternative (60 vs. 109 km; Fig. 1, Table 3). Accordingly, migration times ranged from $2.4,5$ and $22 \mathrm{~d}$ for fish released in Etne, depending on the progression rate and choice of route.

There was a large variation in predicted infection in the different experimental periods (Table 4). These predictions are not location-specific, but show that individuals that use $>10 \mathrm{~d}$ to exit the fjord in periods with high infestation pressure are likely to get lethally high sea-lice infestations.
Table 4. Prediction of lice (Lepeophtheirus salmonis) infection as number of lice per host in Salmo salar after 10, 20, 30 and $40 \mathrm{~d}$ with lice intensity growth rates (Igr) estimated from sentinel cages. Mean = geometric mean intensity from linear mixed modeling using each cage as a random factor; Q75 and Q95 = 75th and 95th percentiles within each cage, averaged over all cages; High(cagemean) = highest cage mean Igr observed across all cages within each experiment; High(cagemax) = maximum observed Igr across all cages within each experiment. Period refers to time interval for cage experiments in 2014 (see also Fig. 5 and Fig. S9 in the Supplement), with $1=$ 8-22 May, 2 = 22 May-5 Jun, 3 = 5-21 Jun, 4 = 15 Aug-2 Sep

\begin{tabular}{|c|c|c|c|c|c|c|}
\hline Year & Period & Igr & $10 \mathrm{~d}$ & $20 \mathrm{~d}$ & $30 \mathrm{~d}$ & $40 \mathrm{~d}$ \\
\hline 2006 & & Mean & 0.4 & 0.9 & 1.3 & 1.8 \\
\hline 2007 & & Mean & 0.9 & 1.9 & 2.8 & 3.8 \\
\hline 2014 & 1 & Mean & 0.2 & 0.4 & 0.6 & 0.8 \\
\hline 2014 & 2 & Mean & 0.3 & 0.5 & 0.8 & 1.0 \\
\hline 2014 & 3 & Mean & 3.1 & 6.1 & 9.2 & 12.2 \\
\hline 2014 & 4 & Mean & 2.5 & 5.0 & 7.5 & 10.0 \\
\hline 2006 & & Q75 & 0.8 & 1.6 & 2.3 & 3.1 \\
\hline 2007 & & Q75 & 1.3 & 2.6 & 3.8 & 5.1 \\
\hline 2014 & 1 & Q75 & 0.2 & 0.4 & 0.6 & 0.8 \\
\hline 2014 & 2 & Q75 & 0.3 & 0.6 & 1.0 & 1.3 \\
\hline 2014 & 3 & Q75 & 4.7 & 9.4 & 14.0 & 18.7 \\
\hline 2014 & 4 & Q75 & 4.0 & 8.1 & 12.1 & 16.2 \\
\hline 2006 & & Q95 & 1.4 & 2.9 & 4.3 & 5.8 \\
\hline 2007 & & Q95 & 1.8 & 3.6 & 5.4 & 7.2 \\
\hline 2014 & 1 & Q95 & 0.9 & 1.7 & 2.6 & 3.4 \\
\hline 2014 & 2 & Q95 & 1.1 & 2.1 & 3.2 & 4.3 \\
\hline 2014 & 3 & Q95 & 6.6 & 13.2 & 19.9 & 26.5 \\
\hline 2014 & 4 & Q95 & 5.5 & 11.0 & 16.5 & 22.0 \\
\hline 2006 & & High(cagemean) & 1.6 & 3.1 & 4.7 & 6.3 \\
\hline 2007 & & High(cagemean) & 3.0 & 6.0 & 9.0 & 12.0 \\
\hline 2014 & $1 \mathrm{H}$ & High(cagemean) & 0.6 & 1.2 & 1.8 & 2.5 \\
\hline 2014 & $2 \mathrm{H}$ & High(cagemean) & 1.2 & 2.3 & 3.5 & 4.6 \\
\hline 2014 & $3 \mathrm{H}$ & High(cagemean) & 11.2 & 22.4 & 33.6 & 44.7 \\
\hline 2014 & $4 \mathrm{I}$ & High(cagemean) & 18.8 & 37.5 & 56.3 & 75.0 \\
\hline 2006 & & High(cagemax) & 4.7 & 9.4 & 14.1 & 18.8 \\
\hline 2007 & & High(cagemax) & 5.5 & 10.9 & 16.4 & 21.8 \\
\hline 2014 & 1 & High(cagemax) & 2.9 & 5.7 & 8.6 & 11.4 \\
\hline 2014 & 2 & High(cagemax) & 5.0 & 10.0 & 15.0 & 20.0 \\
\hline 2014 & 3 & High(cagemax) & 27.5 & 55.0 & 82.5 & 110.0 \\
\hline 2014 & 4 & High(cagemax) & 31.1 & 62.2 & 93.3 & 124.4 \\
\hline
\end{tabular}

\section{DISCUSSION}

We observed no significant differences in progression rates between fish from the 3 different release locations and years (Opo in 2006, Guddal in 2007 and Etne in 2014), between fish of differing genetic background (domesticated, F1 hybrid and wild), and between fish that had received prophylactic treatment against salmon lice and their controls. The progression rates in this study were within the range of previous observations for both wild and domesticated fish (Davidsen et al. 2009, Thorstad et al. 2012a, Vollset et al. 2016a,c). 
a)

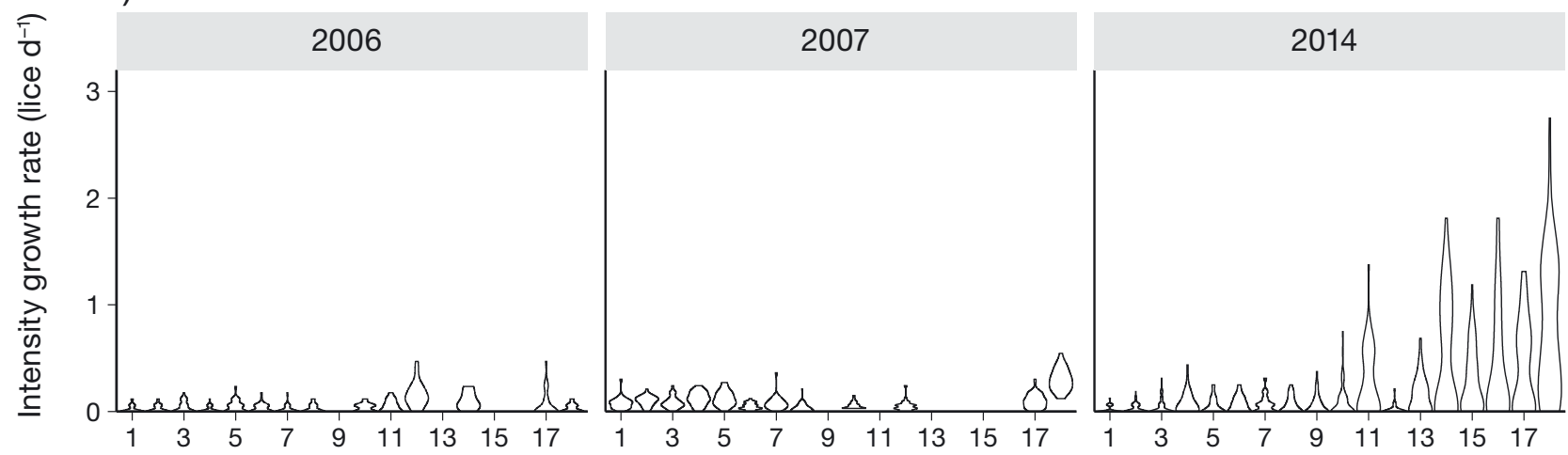

b)
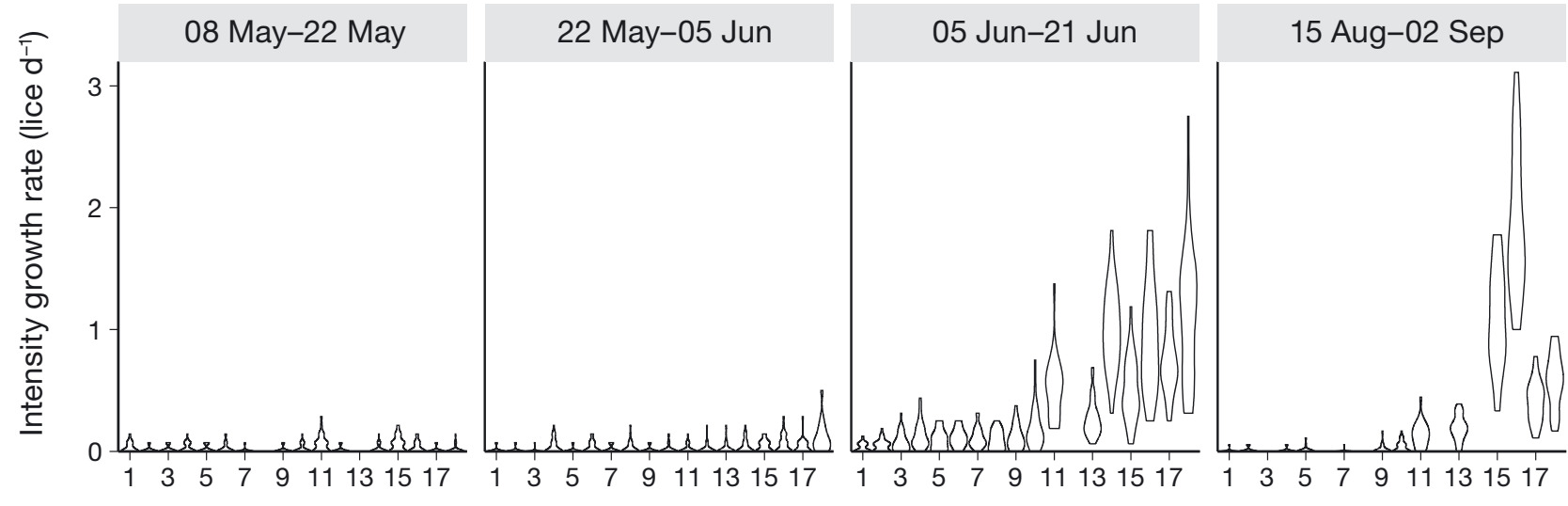

Cage

Fig. 5. Density plots (vertically aligned) of instantaneous intensity growth rates of lice Lepeophtheirus salmonis on hatcheryreared Salmo salar smolts held in sentinel cages in Hardangerfjord. Cages numbered from east to west (see Fig. S3 in the Supplement). (a) Late May to mid-June in the 3 years of the experimental releases. For 2014, the mean of the second and third period was used. (b) Seasonal change in 2014

Although the progression rate was similar at the release location level, both individual variability in progression rate and route choice created large individual differences in fjord residency times (as also observed by Dempson et al. 2011) and therefore in potential lice loads upon exit. The large variability in progression rates among individual fish had the largest consequences for fish released at the innermost site, Opo. The fastest fish took just a week from Opo to reach the open sea, whereas the slowest fish used 3-5 wk to cover the same distance. The impact of different route choices was largest for fish released at the outermost site, Etne. After leaving Etnefjord, the fish that chose the longest route almost doubled the distance they had to cover before reaching the open sea.

Hydrographic conditions can elicit a strong impact on the progression rate and route. The early-release group in Etne experienced lower temperatures than the late-release group, and faced a stronger inflowing current the first day after release, followed by $2 \mathrm{~d}$ of shifting currents with a net flow out of the fjord. These factors may explain the lower swimming speed, higher progression rate and more direct routes out of the fjord compared to the late release. In contrast, after the first day at sea, the late-release group experienced a strong inflowing current, which was associated with much slower progression rates and use of all 4 possible exits. In Guddal, fish chose different routes when released during different phases of the tide, another indication that hydrographic conditions influence the choice of migratory route.

Swimming speeds were generally higher than the progression rates, indicating that most fish did not swim directly to the outer straits, but had longer migration trajectories than the shortest migration route used to calculate the progression rate. This is supported by 2 other observations: (1) many fish were observed to reverse swimming direction, and (2) some fish were observed at several exits before choosing their final exit route. This implies that fastmoving fish may spend equally long times within the 
fjord as their slower counterparts, and due to covering larger distances, experience higher encounter rates with salmon lice.

Based on hydrodynamic considerations, the optimal cruising speed for a migrating fish can be expected to scale with BL to a power of 0.4 (Ware 1978). This is in the middle between the present study's power values of 0.25 and 0.57 found for progression rate and swimming speed, respectively, although these values were not significantly different from 0 . Nevertheless, it can be assumed that larger fish swim faster than smaller fish in absolute terms. The post-smolts used in the present study were of hatchery origin, and were larger (17.7 $\mathrm{cm}$ overall mean length) than the typical wild post-smolt $(14.2 \mathrm{~cm}$ overall mean length for wild trawl-caught post-smolt). Therefore, mean progression rates for a mean-sized wild fish might be expected to be around 9-12 $\mathrm{km} \mathrm{d}^{-1}$, assuming that fish of wild and hatchery origin migrate in similar patterns. This assumption may well hold true, since postsmolts of either origin did not have previous experience with the sea and needed to rely on their genetic instincts to migrate to the ocean. Thus, although approximately half of the wild fish of the rivers Etne and Guddal would have left the fjord within $1 \mathrm{wk}$, a substantial part of the population would have spent many more days to reach the ocean. The majority of wild fish from River Opo must be expected to use $>2$ wk reaching the ocean.

The infestation estimates predicted here are likely to be underestimates for the following reasons. These estimates were based on infestation intensity growth rates on fish held in sea cages for approximately 14-16 d, giving a relatively long exposure time for all individuals. However, the properties of the cages may be biasing the infection intensities downwards (Bjørn et al. 2011). In the cages, captive fish are prevented from swimming freely, and it is unlikely that fish will swim at a speed of around $2 \mathrm{BL} \mathrm{s}^{-1}$ as we observed for free-swimming fish. Moreover, the net walls are relatively fine-meshed and will tend to reduce the flow through the cage as opposed to outside the cage. Both the reduced swimming speed and the reduced flow effects will reduce the encounter rates between drifting salmon lice and post-smolts, and hence bias the salmon lice intensity growth rates downwards. Furthermore, the lice load predictions presented here only took into account the migration from the river outlet to the coast. Little is known about the migration routes of post-smolts further out at sea. Hence it is difficult to take into account further infestation increase off or along the coast. The large variation in both migration distances and progression rates found in this study imply that some fish caught in the trawl may have been at sea for just a few days, whereas others may have been at sea for weeks and therefore reached high lice-infection intensity levels. This explains why the prevalence was lower on postsmolts in the trawl catches compared to the cages, whereas the higher intensity in trawl catches could be taken as support for underestimation of lice intensity growth rates in cages.

It is clear that large parts of wild Atlantic salmon populations migrating long distances in the Hardangerfjord are likely to be exposed to high and threatening infestations during their migration. This indicates that the lower Atlantic-salmon density in populations with long fjord migrations compared to populations with short migration distances (Vollset et al. 2014) may in part be caused by elevated mortality caused by higher salmon-lice infections during outmigration. Vollset et al. (2016b) also found that the effect of salmon lice prophylactic treatment on the survival of Atlantic salmon was greater in years with low baseline survival. In other words, in years with high baseline survival, additional mortality from salmon lice infection may have little effect, whereas in years with low baseline survival, salmon lice infection may be an important mortality factor. Our findings that most fish would reach the ocean with relatively low levels of lice infections in years with low lice intensity growth rates, whereas substantial parts of the Atlantic salmon populations would get critically high lice infections in years with high intensity growth rates, supports this interpretation.

We found no difference in survival or migratory behaviour between the treatment groups in the Etne release. We expect the exposure to salmon lice to be similar for both groups during coastal migration, as the prophylaxis aborts moulting of the lice but does not prevent the initial attachment. This implies that the earliest attached stages do not affect the performance or behaviour of migrating post-smolts as concluded in another release study by Sivertsgård et al. (2007). The fish in that study left the main part of Hardangefjord within $4 \mathrm{~d}$ (range: 1-11 d) after the releases, while the salmon louse needs at least 11$24 \mathrm{~d}$ (in $10-15^{\circ} \mathrm{C}$; quicker in higher temperatures) to develop into more harmful mobile stages (Heuch et al. 2005, Johnson 2006, Samsing et al. 2016, S. Dalvin unpubl. data). We conclude that treating outmigrating post-smolts may have long-term effects on survival and return rates, as it prevents salmon lice moulting into the first chalimus stage, but that treatment has no apparent effect on short-term survival and coastal migration behaviour of the fish. 
Finally, farmed escapees and genetic interactions with wild conspecifics represent one of the major challenges to a sustainable aquaculture industry (Taranger et al. 2015, Forseth et al. 2017, Glover et al. 2017). McGinnity et al. (1997) found a differential mortality in the marine environment between domesticated and wild salmon. We suggest that as the offspring of domesticated Atlantic salmon display overlapping age, size and timing of migration (Skaala et al. 2012), and have similar progression rates out of coastal waters as found in the present study, the differential mortality is likely caused by some other factor than mean progression rate during the early marine phase. However, this requires further studies, preferably involving predator avoidance.

\section{CONCLUSIONS AND MANAGEMENT IMPLICATIONS}

This study has demonstrated that the combination of hydrographic mapping and tracking of post-smolt migration provides important information for management. The migratory routes of Atlantic salmon postsmolts are influenced by currents and can change under changing environmental conditions. In particular, in fjords offering several alternative routes to reach the open ocean, changing currents can cause a variety of migration routes even from the same locality. The drastically different routes chosen by the Etne fish between releases illustrate this, as the different routes between the releases conform to the currents in the main fjord. The variable migratory routes have important implications. One of the management strategies used by the Norwegian government in the study area has been to synchronically fallow sections of the fjord (production zones), in order to reduce the encounter rate of salmon lice and wild salmonids (Norwegian Food Safety Authorities, www.mattilsynet.no). However, as the post-smolts spread across the fjord and enter other fjords, this implies that the fish pass through several production zones in different phases of the fallowing regime. Therefore, the effect of the fallowing zones is diminished considerably. It is important to note also that the acquired lice infections predicted in this study are conservative (underestimated), as there are strong reasons to believe that the lice intensity growth rates the predictions were based on were biased downwards. We conclude that as the migratory routes of Atlantic salmon post-smolts are hard to predict, it is of utmost importance to keep salmon lice levels down in all management zones during the full potential migration period.
Acknowledgements. Before he completed the analyses upon which this study is based, Ove T. Skilbrei suddenly died. We dedicate this work to his memory - a colleague and friend who provided us with a unique insight into the ecology and biology of the Atlantic salmon. We thank Sofie Knutar, Kristine Marit Schrøder Elvik, Pablo Arechavala-Lopez and the crew of RVs 'Fangst' and 'Brattstrøm' for their aid during the fieldwork. The study was funded by the Institute of Marine Research and the Research Council of Norway (LicePop, project no. 221404).

\section{LITERATURE CITED}

Albretsen J, Sperrevik AK, Staalstrøm A, Sandvik AD, Vikebø F, Asplin L (2011) NorKyst-800 report no. 1: user manual and technical descriptions. Fisken Havet 2:1-48

Birkeland K (1996) Consequences of premature return by sea trout (Salmo trutta) infested with the salmon louse (Lepeophtheirus salmonis Kroyer): migration, growth, and mortality. Can J Fish Aquat Sci 53:2808-2813

* Bjørn PA, Finstad B (1998) The development of salmon lice (Lepeophtheirus salmonis) on artificially infected post smolts of sea trout (Salmo trutta). Can J Zool 76:970-977

Bjørn PA, Sivertsgard R, Finstad B, Nilsen R, Serra-Llinares RM, Kristoffersen R (2011) Area protection may reduce salmon louse infection risk to wild salmonids. Aquacult Environ Interact 1:233-244

Davidsen JG, Rikardsen AH, Halttunen E, Thorstad EB and others (2009) Migratory behaviour and survival rates of wild northern Atlantic salmon Salmo salar post-smolts: effects of environmental factors. J Fish Biol 75: $1700-1718$

*Dempson JB, Robertson MJ, Pennell CJ, Furey G and others (2011) Residency time, migration route and survival of Atlantic salmon Salmo salar smolts in a Canadian fjord. J Fish Biol 78:1976-1992

Finstad B, Bjørn PA, Grimnes A, Hvidsten NA (2000) Laboratory and field investigations of salmon lice Lepeophtheirus salmonis (Kroyer) infestation on Atlantic salmon (Salmo salar L.) post-smolts. Aquacult Res 31:795-803

Finstad B, Økland F, Thorstad EB, Bjørn PA, McKinley RS (2005) Migration of hatchery-reared Atlantic salmon and wild anadromous brown trout post-smolts in a Norwegian fjord system. J Fish Biol 66:86-96

*Forseth T, Barlaup BT, Finstad B, Fisk P and others (2017) The major threats to Atlantic salmon in Norway. ICES J Mar Sci 74:1496-1513

Gargan PG, Forde G, Hazon N, Russell DJF, Todd CD (2012) Evidence for sea lice-induced marine mortality of Atlantic salmon (Salmo salar) in western Ireland from experimental releases of ranched smolts treated with emamectin benzoate. Can J Fish Aquat Sci 69:343-353

Gjelland KØ, Hedger RD (2013) Environmental influence on transmitter detection probability in biotelemetry: developing a general model of acoustic transmission. Methods Ecol Evol 4:665-674

Gjelland KØ, Hedger RD (2017) On the parameterization of acoustic detection probability models. Methods Ecol Evol 8:1302-1304

Gjelland KØ, Serra-Llinares RM, Hedger RD, ArechavalaLopez P and others (2014) Effects of salmon lice infection on the behaviour of sea trout in the marine phase. Aquacult Environ Interact 5:221-233

*Glover KA, Otterå H, Olsen RE, Slinde E, Taranger GL, 
Skaala Ø (2009) A comparison of farmed, wild and hybrid Atlantic salmon (Salmo salar L.) reared under farming conditions. Aquaculture 286:203-210

Glover KA, Solberg MF, McGinnity P, Hindar K and others (2017) Half a century of genetic interaction between farmed and wild Atlantic salmon: status of knowledge and unanswered questions. Fish Fish 18:890-927

* Godwin SC, Dill LM, Reynolds JD, Krkosek M (2015) Sea lice, sockeye salmon, and foraging competition: lousy fish are lousy competitors. Can J Fish Aquat Sci 72: 1113-1120

KHandeland SO, Järvi T, Fernö A, Stefansson SO (1996) Osmotic stress, antipredatory behaviour, and mortality of Atlantic salmon (Salmo salar) smolts. Can J Fish Aquat Sci 53:2673-2680

Hedger RD, Uglem I, Thorstad EB, Finstad B and others (2011) Behaviour of Atlantic cod, a marine fish predator, during Atlantic salmon post-smolt migration. ICES J Mar Sci 68:2152-2162

Heuch PA, Bjørn PA, Finstad B, Holst JC, Asplin L, Nilsen F (2005) A review of the Norwegian 'National Action Plan Against Salmon Lice on Salmonids': the effect on wild salmonids. Aquaculture 246:79-92

Holst JC, McDonald A (2000) FISH-LIFT: a device for sampling live fish with trawls. Fish Res 48:87-91

Huveneers C, Stehfest KM, Simpfendorfer CA, Semmens J and others (2017) Application of the acoustic propagation model to a deep-water cross-shelf curtain. Methods Ecol Evol 8:1305-1308

Hvidsten NA, Lund RA (1988) Predation on hatchery-reared and wild smolts of Atlantic salmon, Salmo salar L., in the estuary of River Orkla, Norway. J Fish Biol 33:121-126

Jackson D, Cotter D, Newell J, McEvoy S and others (2013) Impact of Lepeophtheirus salmonis infestations on migrating Atlantic salmon, Salmo salar L., smolts at eight locations in Ireland with an analysis of lice-induced marine mortality. J Fish Dis 36:273-281

Johnson SC (2006) A comparison of development and growth rates of Lepeophtheirus salmonis (Copepoda: Caligidae) on naive Atlantic (Salmo salar) and chinook (Oncorhynchus tshawytscha) salmon. In: Boxshall G, Defaye D (eds) Pathogens of wild and farmed fish: sea lice. Ellis Horwood, Chichester, p 68-82

McGinnity P, Stone C, Taggart JB, Cooke D and others (1997) Genetic impact of escaped farmed Atlantic salmon (Salmo salar L.) on native populations: use of DNA profiling to assess freshwater performance of wild, farmed, and hybrid progeny in a natural river environment. ICES J Mar Sci 54:998-1008

* Overli O, Nordgreen J, Mejdell CM, Janczak AM, Kittilsen S, Johansen IB, Horsberg TE (2014) Ectoparasitic sea lice (Lepeophtheirus salmonis) affect behavior and brain serotonergic activity in Atlantic salmon (Salmo salar L.): perspectives on animal welfare. Physiol Behav 132:44-50

* Peacock SJ, Krkošek M, Bateman AW, Lewis MA (2015) Parasitism and food web dynamics of juvenile Pacific salmon. Ecosphere 6:1-16

Samsing F, Oppedal F, Dalvin S, Johnsen I, Vågseth T, Dempster T (2016) Salmon lice (Lepeophtheirus salmonis) development times, body size, and reproductive outputs follow universal models of temperature dependence. Can J Fish Aquat Sci 73:1841-1851

Serra-Llinares RM, Bjørn PA, Finstad B, Nilsen R, Harbitz A, Berg M, Asplin L (2014) Salmon lice infection on wild salmonids in marine protected areas: an evaluation of the
Norwegian 'National Salmon Fjords'. Aquacult Environ Interact 5:1-16

* Serra-Llinares RM, Bjørn PA, Finstad B, Nilsen R, Asplin L (2016) Nearby farms are a source of lice for wild salmonids: a reply to Jansen et al. (2016). Aquacult Environ Interact 8:351-356

* Shephard S, MacIntyre C, Gargan P (2016) Aquaculture and environmental drivers of salmon lice infestation and body condition in sea trout. Aquacult Environ Interact 8: $597-610$

* Simpfendorfer CA, Heupel MR, Hueter RE (2002) Estimation of short-term centers of activity from an array of omnidirectional receivers and its use in studying animal movements. Can J Fish Aquat Sci 59:23-32

Kivertsgard R, Thorstad EB, Okland F, Finstad B and others (2007) Effects of salmon lice infection and salmon lice protection on fjord migrating Atlantic salmon and brown trout post-smolts. Hydrobiologia 582:35-42

* Skaala Ø, Glover KA, Barlaup BT, Svåsand T, Besnier F, Hansen MM, Borgstrøm R (2012) Performance of farm, hybrid and wild Atlantic salmon (Salmo salar) families in a natural river environment. Can J Fish Aquat Sci 69: 1994-2006

Skaala Ø, Kålås S, Borgstrøm R (2014) Evidence of salmon lice-induced mortality of anadromous brown trout (Salmo trutta) in the Hardangerfjord, Norway. Mar Biol Res 10:279-288

* Skilbrei OT, Finstad B, Urdal K, Bakke G, Kroglund F, Strand R (2013) Impact of early salmon louse, Lepeophtheirus salmonis, infestation and differences in survival and marine growth of sea-ranched Atlantic salmon, Salmo salar L, smolts 1997-2009. J Fish Dis 36:249-260

Skilbrei OT, Espedal PG, Nilsen F, Garcia EP, Glover KA (2015) Evaluation of emamectin benzoate and substance EX against salmon lice in sea-ranched Atlantic salmon smolts. Dis Aquat Org 113:187-194

* Strand R, Finstad B (2007) Migratory behaviour in relation to smolt development and releasing strategies in Atlantic salmon (Salmo salar L.) smolts. Aquaculture 273:277-283

* Strand JET, Davidsen JG, Jorgensen EH, Rikardsen AH (2011) Seaward migrating Atlantic salmon smolts with low levels of gill $\mathrm{Na}+\mathrm{K}+$-ATPase activity; is sea entry delayed? Environ Biol Fishes 90:317-321

* Taranger GL, Karlsen O, Bannister RJ, Glover KA and others (2015) Risk assessment of the environmental impact of Norwegian Atlantic salmon farming. ICES J Mar Sci 72: 997-1021

Thorstad EB, Økland F, Finstad B, Sivertsgård R, Bjørn PA, McKinley RS (2004) Migration speed and orientation of Atlantic salmon and sea trout post-smolts in a Norwegian fjord system. Environ Biol Fishes 71:305-311

* Thorstad EB, Whoriskey F, Uglem I, Moore A, Rikardsen A, Finstad B (2012a) A critical life stage of the Atlantic salmon Salmo salar: behavior and survival during the smolt and initial post-smolt migration. J Fish Biol 81: $500-542$

* Thorstad EB, Uglem I, Finstad B, Chittenden CM, Nilsen R, Okland F, Bjorn PA (2012b) Stocking location and predation by marine fishes affect survival of hatchery-reared Atlantic salmon smolts. Fish Manag Ecol 19:400-409

Tully O, Nolan DT (2002) A review of the population biology and host-parasite interactions of the sea louse Lepeophtheirus salmonis (Copepoda: Caligidae). Parasitology 124: S165-S182

Vollset KW, Skoglund H, Barlaup BT, Pulg U and others 
(2014) Can the river location within a fjord explain the density of Atlantic salmon and sea trout? Mar Biol Res 10: 268-278

Vollset KW, Barlaup BT, Mahlum S, Bjørn PA, Skilbrei OT (2016a) Estimating the temporal overlap between postsmolt migration of Atlantic salmon and salmon lice infestation pressure from fish farms. Aquacult Environ Interact 8:511-525

Vollset KW, Krontveit RI, Jansen PA, Finstad B and others

Editorial responsibility: Alistair Hobday,

Hobart, Tasmania, Australia (2016b) Impacts of parasites on marine survival of Atlantic salmon: a meta-analysis. Fish Fish 17:714-730

* Vollset KW, Mahlum S, Davidsen JG, Skoglund H, Barlaup BT (2016c) Interaction between migration behaviour and estuarine mortality in cultivated Atlantic salmon Salmo salar smolts. J Fish Biol 89:1974-1990

*Ware DM (1978) Bioenergetics of pelagic fish: theoretical change in swimming speed and ration with body size. J Fish Res Board Can 35:220-228

Submitted: April 27, 2017; Accepted: November 2, 2017 Proofs received from author(s): December 22, 2017 